\title{
Determinants of sputum smear nonconversion in smear-positive pulmonary tuberculosis patients in Suriname, $2010-2015$
}

\author{
Eric Commiesie, ${ }^{1}$ Deborah Stijnberg, ${ }^{1}$ Diana Marín, ${ }^{2}$ Freddy Perez, ${ }^{3}$ and Mauro Sanchez ${ }^{4}$
}

Suggested citation Commiesie E, Stijnberg D, Marín D, Perez F, Sanchez M. Determinants of sputum smear nonconversion in smear-positive pulmonary tuberculosis patients in Suriname, 2010-2015. Rev Panam Salud Publica. 2019;43:e86. https://doi.org/10.26633/ RPSP.2019.86

ABSTRACT Objective. To identify factors associated with sputum smear nonconversion in patients with pulmonary tuberculosis (PTB) in Suriname.

Methods. A case-control study was conducted using routinely-collected surveillance data of PTB cases reported in January 2010 - December 2015 and recorded in the database of the National Tuberculosis Program of Suriname. Cases were smear-positive PTB patients whose sputum results were negative 2 months after treatment initiation. Controls were the smear-positive PTB patients whose sputum results were negative in the same timeframe. Multivariate logistic regression analysis was used to examine associations between potential risk factors and smear conversion.

Results. The two age groups $\geq 35$ years (35 - 54 years, AOR: 2.7, 95\%Cl: $1.2-6.1$; and 55+ years, AOR: 2.5, $95 \% \mathrm{Cl}: 1.1-5.9$ ) and high bacillary load at baseline (AOR 2.34, 95\% Cl: $1.2-4.8$ ) were significantly associated with delayed smear conversion.

Conclusion. The National TB program of Suriname should develop strategies to address patients at higher risk for delayed smear conversion to prevent further spreading and unfavorable treatment outcomes. To better inform decision-making and future studies, the NTP should expand its data collection to include all risk factors for delayed smear conversion.

Keywords Tuberculosis, pulmonary; treatment outcome; sputum; risk factors, tuberculosis; Suriname.

Tuberculosis (TB) continues to be a global health problem with an estimated 10 million cases annually. According to the Global Tuberculosis Report 2017, in the past 5 years TB has caused more deaths than any other single infectious disease, including HIV/AIDS (1). The TB situation challenges the 2030 Sustainable Development Goal targets of reducing TB deaths by $90 \%$ and the TB incidence rate by $80 \%$ (2). According to the Global Tuberculosis Report 2017, there were an estimated 10.4 million patients with TB in 2016 , of which $90 \%$ were adults, $65 \%$ male, and $10 \%$ people living with HIV (1). In 2016, new TB cases in the Region of the Americas were estimated at 274000 . Of these, $140(0.05 \%)$ were reported by Suriname. In the same year, both the Region of the Americas and Suriname had treatment success rates close to $76 \%$ for new and relapsed cases $(1,3)$.

The Republic of Suriname is located on the northeast coast of South America, bordered by the Atlantic Ocean to the north, Brazil to the south, French Guiana to the east, and Guyana to the west. The country has a total land area of $163820 \mathrm{~km}^{2}$. The

\footnotetext{
Ministry of Health, Paramaribo, Suriname. $\bowtie$ ercom75@gmail.com

2 Universidad Pontificia Bolivariana, Medellín, Colombia.

3 Department of Communicable Diseases and Environmental Determinants of Health, Pan American Health Organization/World Health Organization, Washington, DC, United States of America.
}

\footnotetext{
4 Universidade de Brasilia, Brasilia, Brazil.
} 
coastal area comprises two urban and six rural districts; the interior has two districts. The two urban districts, Paramaribo (the capital) and Wanica, cover $0.5 \%$ of the country's land and contain $70 \%$ of its population (4), which in 2017 was estimated to be 563402 (5). The estimated TB incidence rate was 29 per 100 000 population; for TB/HIV, 4.7; and for rifampicin/multidrug resistance, 2.0 (3).

The National Tuberculosis Program of Suriname (NTP), within the Bureau of Public Health of the Ministry of Health, is responsible for TB policy development, supervision, treatment, patient follow-up, and monitoring and evaluation. TB case finding is passive in Suriname. Diagnosis is established through sputum smear microscopy and chest radiography for pulmonary TB (PTB) and other systemic investigations for extra-pulmonary disease. Xpert $^{\circledR}$ MTB/RIF assay (Cepheid, Sunnyvale, California, United States; Xpert) has been used as a diagnostic tool since 2012 in Suriname.

All TB diagnostic services and treatment are free of charge in Suriname. Patients are classified according to WHO definitions and the reporting framework for tuberculosis (6). Presumptive TB patients can be referred by a family doctor to the lung clinics of the Academic Hospital Suriname or can use NTP walk-in service. In the interior of the country, patients can visit the Medical Mission; and in remote parts of the coastal area, the Regional Health Service (RGD).

Patients with delayed smear conversion 2 months after treatment initiation remain potentially infectious and are more likely to have unfavorable treatment outcomes (7). Pefura and colleagues stated that $5 \%-30 \%$ of patients with a first episode of smear-positive PTB remain positive after 2 months of treatment (8). In patients with PTB, shortening the time to sputum conversion is desirable to reduce the likelihood of mycobacterial transmission.

Several factors, such as male sex, older age, higher baseline sputum grade, smoking habits, extensive disease involvement on chest x-ray $(7,9-13)$, and diabetes mellitus $(14-17)$ have been identified in previous studies as risk factors for delayed smear conversion. On the other hand, Saffari and colleagues (18) found no association between delayed smear conversion and addictions, alcoholism, diabetes mellitus, or sex. The association between HIV status and smear conversion has not been fully understood. Senkoro and colleagues (15) demonstrated that HIV status did not influence sputum smear conversion. On the other hand, Kayigamba and colleagues (14) and Mlotshwa and colleagues (19) highlighted that HIV was an important predictor of sputum smear nonconversion among smear-positive PTB patients.

Predictors of smear nonconversion at baseline can help identify cases at risk for failure of TB treatment. To date, no such study has been conducted in Suriname. Therefore, the objective of this study was to identify factors associated with sputum smear nonconversion in PTB patients in Suriname in order to better guide national policy and clinical management of patients.

\section{MATERIALS AND METHODS}

\section{Study design}

This was a case-control study based on surveillance data collected in 2010 - 2015 by the NTP of Suriname. The study included all new and previously-treated, smear-positive PTB patients who were diagnosed in 2010 - 2015 and whose cases were notified to NTP and registered in the electronic National TB database. A TB register was used to complete the dataset with data regarding the degree of sputum smear positivity.

Patients $<15$ years of age with no sputum smear result 2 months after treatment initiation, not treated, or lost to followup before 2 months (including patients who died) were excluded from the study. Also excluded were non-pulmonary patients, smear-negative PTB patients, and patients with unknown sputum smear status at treatment initiation.

Cases and control definitions. A case of sputum smear nonconversion was defined as a patient with PTB, who had a positive smear at treatment initiation and remained positive after 2 months of treatment. A control was defined as the same except that the smear was negative after 2 months of treatment.

Diagnosis. The Medical Mission (in the interior) and the RGD (coastal area) collect sputum in presumptive TB cases and do treatment follow-up in their respective service areas. TB microscopy diagnosis is performed centrally, in Paramaribo, at the Central Laboratory of the Bureau of Public Health or at the Laboratory of the Academic Hospital. Both laboratories used Ziehl Nielsen for staining and perform Xpert. Only the Central Laboratory performs TB culture. TB patients are routinely admitted and treated in the Sanatorium (Academic Hospital TB ward) until they are smear negative.

\section{Variables and data collection}

The following data were collected for all patients: year of registration; age at time of diagnosis; sex; time (in days) since starting treatment (calculated by subtracting date of TB treatment initiation from date of admission/first positive smear); grade of smear positivity at baseline $(\leq 1+, 2+$ and $\geq 2+)$; HIV status (negative/positive/unknown); anti-retroviral therapy (ART; yes/no/ unknown); Directly Observed Treatment (yes/ no/unknown); hospitalization (yes/ no/unknown); days of hospitalization; case type (new/retreatment); rifampicin sensitivity (resistant/sensitive/unknown); and comorbidity with diabetes mellitus (DM).

Among these variables, the label "unknown" refers to missing data. Factors such as being homeless, smoking, being incarcerated (or $<2$ years out of prison), and alcohol and drug use were categorized together as "other risk factor" in 2010 - 2011, but as individual factors in 2012 - 2015. Therefore, in order to analyze the entire study period, the individual factors were re-coded as "other risk factor." However, many of the "other risk factor" variables were categorized as "unknown" (missing), which could have resulted in a bias if all cases with missing data were excluded (178 of 469 cases). To resolve the issue, the association between this variable and others, as well as its effect on the model, were evaluated. It was determined that there was no significant improvement or change in the model explanation capability, so "other risk factor" was eliminated from the analysis.

The criterion "hospitalized" was defined as a hospital stay of $\geq 14$ days. Several studies indicate that after treatment with 
multiple drugs, TB cases become smear negative in $2-3$ weeks (13). Cases not admitted or admitted for $<14$ days were classified as "not hospitalized."

\section{Analysis}

Data were exported from Microsoft Access $^{\mathrm{TM}}$ to a Microsoft Excel $^{\mathrm{TM}}$ database (Microsoft Corp., Redmond, Washington, United States) and statistical analysis was performed using IBM SPSS $^{\circledR}$ Statistics, version 22 (IBM Corp., Armonk, New York, United States) and Stata ${ }^{\circledR} 11.1$ (StataCorp, College Station, Texas, United States). The qualitative variables were described as absolute and relative frequencies; missing or unknown values were retained in the descriptive analysis. Age, time of hospitalization, and time to the start of TB treatment were reported as a median with interquartile range (IQR) because they did not follow a normal distribution. Differences between the cases and controls were assessed using the chi-square test, Fishers exact test, and the likelihood ratio for qualitative variables. The Mann-Whitney U test was used to compare medians.

An extension of the Wilcoxon rank-sum test was used to determine any significant trend in the proportion of sputum smear nonconversion in the cohort of smear-positive PTB patients. Smear status at month 2 was categorized as a binary variable. A bivariate analysis to estimate the Odds Ratio (OR) and the $95 \%$ Confidence Intervals $(95 \% \mathrm{CI})$ was performed. The multivariate logistic regression included those variables that attained a $P$ value $<0.25$ in the bivariate analysis and HIV status. HIV was forced into the model because several studies describe it as a significant predictor for delayed smear conversion and it is of major concern in the TB epidemiology of Suriname $(18.6 \%$ of the study population was HIV-positive). A two-tailed $P$ value $<0.05$ was considered significant.

\section{Ethics}

Ethics approval for this study was obtained from the Human Scientific Research Ethic Committee of the Ministry of Health of Suriname and the PAHO Ethics Committee. Researchers had written permission to use information from the NTP. Identifiable data were removed and not used in data analysis.

\section{RESULTS}

Of 917 records in the NTP database, 469 cases of smearpositive PTB met the study criteria and were included in the analysis (Figure 1).

The median time from diagnosis to the start of treatment was 1 day for cases $(\mathrm{IQR}=0-5)$ versus 4 days for controls $(\mathrm{IQR}=$ $0-8)$. This difference was statistically significant $(P=0.015)$.

Of all the PTB patients, $12.3 \%$ remained smear-positive two months after treatment initiation. No trend in the rate of smear nonconversion was identified in the study period (2010 - 2015). Culture results were available for $89 \%$ of cases and $80 \%$ of controls. Of the controls, $64 \%$ were culture positive and identified as Mycobacterium tuberculosis. Of those with delayed sputum conversion and a culture result available, 94\% had a positive culture at treatment initiation versus $64 \%$ of those whose smear was negative at month 2 . Of the positive cultures, $96 \%$ were identified as Mycobacterium tuberculosis by Xpert.

Not all patients had a rifampicin sensitivity result because Xpert was not implemented until 2012 and not all were tested consistently thereafter.

The multivariate analysis (Table 2) showed that the following factors were significant predictors of delayed smear conversion after adjusting for other factors: age group $35-54$ years (AOR: 2.7, 95\%CI: $1.2-6.1$ ), age group 55+ years (AOR: $2.5,95 \% \mathrm{CI}: 1.1-$ 5.9), and high bacillary load (3+; AOR 2.34, 95\%CI: $1.2-4.8)$.

FIGURE 1. Flow diagram of cases of pulmonary tuberculosis (PTB) analyzed, National Tuberculosis Program (NTP) database, Suriname, $2010-2015$

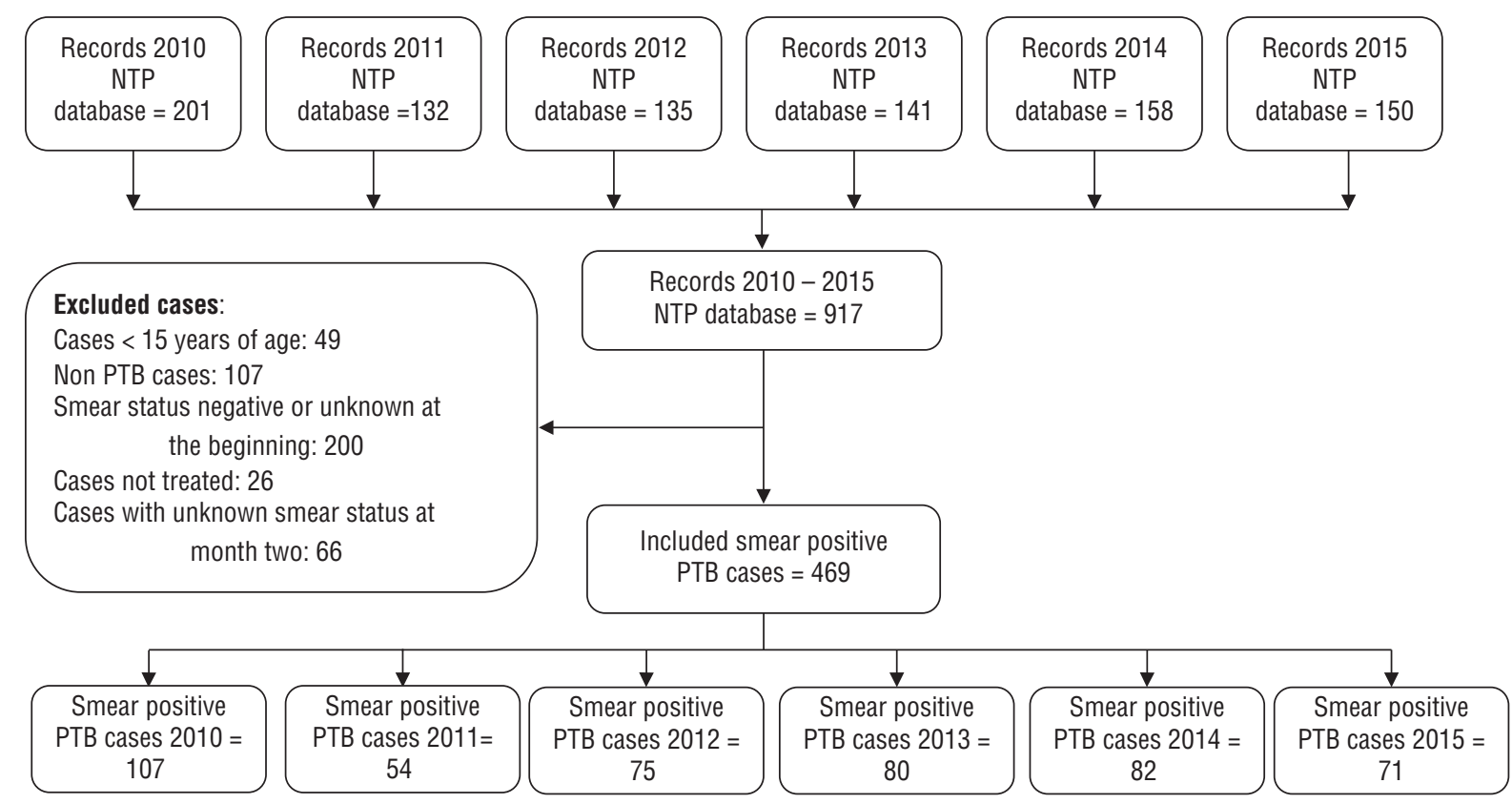

Source: Prepared by the authors from the study results. 
TABLE 1. Demographic, clinical, and programmatic characteristics of smear-positive pulmonary tuberculosis (PTB) patients, Suriname, $2010-2015$

\begin{tabular}{|c|c|c|c|c|c|c|c|}
\hline Characteristic & Total $(n=469)$ & $\%$ & Cases $(n=59)$ & $\%$ & Controls $(n=410)$ & $\%$ & $P$ value \\
\hline \multicolumn{8}{|l|}{ Sex } \\
\hline Male & 349 & 74.4 & 47 & 79.7 & 302 & 73.7 & \multirow[t]{2}{*}{$0.323^{\mathrm{a}}$} \\
\hline Female & 120 & 25.6 & 12 & 20.3 & 108 & 26.3 & \\
\hline Median & 42 & & $43(37-54)$ & & $42(31-51)$ & & $0.126^{\mathrm{a}}$ \\
\hline \multicolumn{8}{|l|}{ Age groups (years) } \\
\hline $55+$ & 71 & 15.1 & 8 & 13.6 & 63 & 15.4 & $0.036^{a}$ \\
\hline \multicolumn{8}{|l|}{ HIV status } \\
\hline Negative & 371 & 79.1 & 45 & 76.3 & 326 & 79.5 & \multirow[t]{3}{*}{$0.413^{b}$} \\
\hline Positive & 87 & 18.6 & 11 & 18.6 & 76 & 18.5 & \\
\hline Unknown & 11 & 2.3 & 3 & 5.1 & 8 & 2.0 & \\
\hline \multicolumn{8}{|l|}{ DOT } \\
\hline Yes & 309 & 65.9 & 41 & 69.5 & 268 & 65.4 & \multirow[t]{2}{*}{$0.532^{\mathrm{a}}$} \\
\hline No & 160 & 34.1 & 18 & 30.5 & 142 & 34.6 & \\
\hline \multicolumn{8}{|l|}{ Hospitalization } \\
\hline Yes & 417 & 88.9 & 53 & 89.8 & 364 & 88.8 & \multirow[t]{3}{*}{$0.898^{b}$} \\
\hline No & 15 & 3.2 & 2 & 3.4 & 13 & 3.2 & \\
\hline Unknown & 37 & 7.9 & 4 & 6.8 & 33 & 8.1 & \\
\hline \multicolumn{8}{|l|}{ Hospitalization (days) } \\
\hline Median (IQR) & $48(30-71)$ & & $93(54-132)$ & & $45(29-66)$ & & \multirow[t]{2}{*}{$<0.001^{\circ}$} \\
\hline \multicolumn{7}{|l|}{ Case type } & \\
\hline New & 430 & 91.7 & 53 & 89.8 & 377 & 92.0 & \\
\hline $3+$ & 170 & 36.2 & 30 & 50.8 & 140 & 34.1 & $0.015^{\mathrm{a}}$ \\
\hline \multicolumn{8}{|c|}{ Time to start TB treatment (days) } \\
\hline Median (IQR) & $3(0-8)$ & & $1(0-5)$ & & 4 & & $0.015^{c}$ \\
\hline \multicolumn{8}{|l|}{ Rifampicin sensitivitye } \\
\hline Resistant & 27 & 5.8 & 4 & 6.8 & 23 & 5.6 & \multirow[t]{3}{*}{$0.398^{b}$} \\
\hline Sensitive & 237 & 50.5 & 34 & 57.6 & 203 & 49.5 & \\
\hline Unknown & 205 & 43.7 & 21 & 35.6 & 184 & 44.9 & \\
\hline
\end{tabular}

\section{DISCUSSION}

This study showed that high bacillary load and age $\geq 35$ years were independently associated with delayed smear conversion in PTB patients. The higher the bacillary load at start of treatment, the stronger the association $(2+$ : AOR 1.77, 95\%CI:
0.8 - 4.0; and 3+: AOR 2.34, 95\%CI: 1.2 -4.8). Several other studies have demonstrated that high bacillary load was associated with delayed clearance of sputum $(8,9,13,16,17)$.

Regarding age group associated with delayed smear conversion, D'Souza and colleagues (9) mentioned a significant association with age $\geq 35$ years. However, Caetano and 
TABLE 2. Multivariate analysis of factors associated with smear nonconversion 2 months after tuberculosis (TB) treatment started, Suriname, $2010-2015(n=458)$

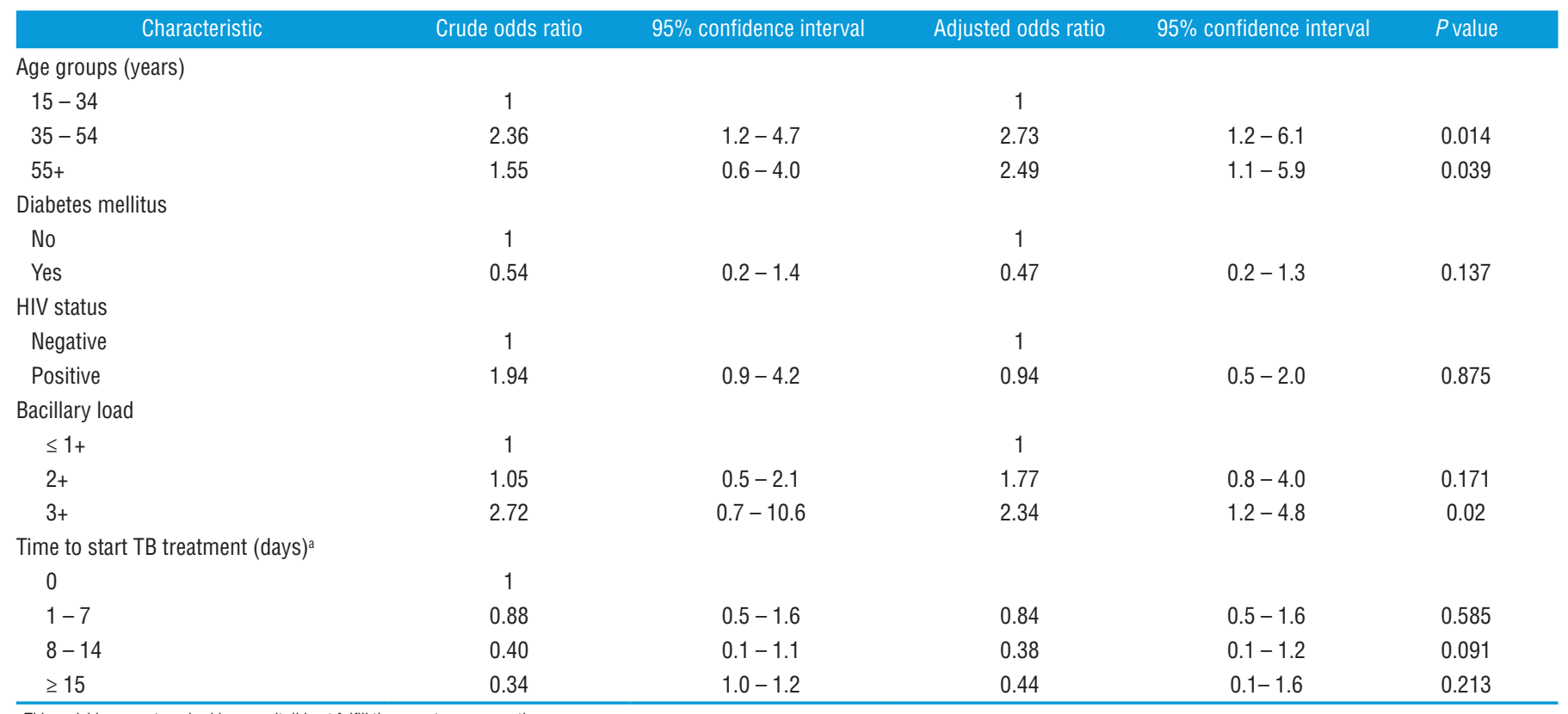

This variable was categorized because it did not fulfill the monotony assumption. Source: Prepared by the authors from the study results.

colleagues (20) and Gunda and colleagues (7) found a significant association with age $\geq 50$ years. Our study findings probably differ from theirs because of the differences in study populations-in the first (20), $40 \%$ of the study population was $\geq 50$ years of age; in the second (7), 67\% was < 34 years. In our study, $51 \%$ was $35-54$ years and $15 \%$ was $55+$ years. To the contrary, Djouma and colleagues (12) and Bisognin and colleagues (13) did not observe a significant association between older age and delayed smear conversion.

The present study did not show a strong association between $\mathrm{DM}$ and smear nonconversion (AOR 0.47, 95\%CI: $0.2-1.3$ ). Other studies, however, have demonstrated a significant association between smear conversion and DM $(21-23)$. This is possibly due to the prevalence of DM in the study populations, and the sample size. The prevalence of DM in our study was $9 \%$ for cases and $15 \%$ for controls, while in Shariff and colleagues (21), it was $41.3 \%$ for cases and $21.3 \%$ for controls. Though in Mi and colleagues (22) DM prevalence was $12 \%$ - similar to its prevalence in our study-those with DM were predominantly male and age $>35$ years, two factors that are described in several studies to be associated with delayed smear conversion (7, $9,15)$. Furthermore, Mi and colleagues did not include data on baseline smear status.

As mentioned, bacillary load is associated with delayed smear conversion. These factors might influence the association with delayed sputum smear conversion found by Mi and colleagues (22). Our study had five cases of TB with DM and delayed smear conversion at month 2 . Of the five, three were female, which differs from the overrepresentation of males in the other study (22). However, additional studies have also found no association between DM and delayed smear conversion $(14,24)$.

HIV coinfection was not associated with delayed smear conversion in this study. The findings of other studies are somewhat contradictory regarding the influence of HIV on smear conversion 2 months after treatment initiation. Some studies (14, 19) describe a significant association between HIV coinfection and delayed sputum smear conversion; while others found no association $(7,15)$. Possible explanations for these differing results might be the severity of the HIV (CD4 count) and degree of adherence to ART. Unfortunately, we did not have data on CD4 levels or ART adherenc. However, a study by Nunn and colleagues described that HIV positive TB cases excrete significantly fewer organism per mL of sputum (25). If the HIV cases in our study predominantly had low bacillary load, it would not have resulted in smear nonconversion. Another possible explanation for not finding an association is that we excluded patients who died prior to receiving 2 months of treatment. These were more likely to be patients with advanced HIV/ AIDS, who would have experienced delayed sputum smear conversion.

\section{Limitations}

This study has some limitations. It is a retrospective analysis so certain known risk factors for delayed smear conversion, such as cavity on chest radiology, smoking habit, and CD4 level of HIV coinfected patients, could not be assessed because the data was not available or lacked detail. In addition, factors such as drug abuse, homelessness, being a prisoner, and smoking were excluded due to missing data (50\%). Patients with an unknown outcome 2 months after treatment were excluded from the study. If these were more likely to delay smear conversion, the associated risk factors may have been underreported. For instance, patients who died before receiving 2 months of treatment were excluded and may have been more associated with HIV-seropositivity. This may have resulted in underrepresentation of HIV as a risk factor. Also, as mentioned, rifampicin 
sensitivity was not available for all cases. However, we believe that rifampicin resistance had no influence on study results. A recent analysis of rifampicin resistant cases (26) found that all cases had the same mutation for low-level resistance, and that after six months of treatment, the outcomes were similar to those of cases susceptible to rifampicin (26).

\section{Conclusions}

The results of this study concur with findings of past studies indicating that higher bacillary load and age $\geq 35$ year are significantly associated with delayed smear conversion. Based on these findings, the NTP of Suriname should develop strategies to improve smear conversion in the identified risk group. Patients with a higher bacillary load and age $\geq 35$ should receive more focused attention to prevent tuberculosis from spreading. In addition, to better inform decision-making as well as future studies, the NTP should expand its data collection to include all risk factors for delayed smear conversion.

Acknowledgements. We would like to thank the staff of the National Tuberculosis Program of Suriname, especially those in the monitoring and evaluation department, as well as the nurses responsible for the data collection. Special thanks to all SORT IT facilitators and participants in the Suriname course. It was a great pleasure to learn from you. Special thanks to Zaida Yadon for her efforts to make the SORT IT project possible in Suriname. We also thank Manuel Sanchez for his support during the SORT IT course.

Funding. The manuscript was produced during a SORT IT training (WHO/TDR initiative) organized with PAHO support; however, no funding was received for either the study or the resulting paper.

\section{Conflicts of interest. None declared.}

Author contributions. EC, DS, DM, FP, and MS conceived the original idea, analyzed the data, interpreted the results, and wrote and reviewed the manuscript. All authors reviewed and approved the final version.

Disclaimer. Authors hold sole responsibility for the views expressed in the manuscript, which may not necessarily reflect the opinion or policy of the RPSP/PAJPH and/or PAHO.

\section{REFERENCES}

1. World Health Organization. Global Tuberculosis Report 2017. Geneva: WHO; 2017.

2. World Health Organization. Global Tuberculosis Report 2018. Geneva: WHO; 2018.

3. World Health Organization. Suriname Tuberculosis County Profile 2017. Geneva: WHO; 2017. Available from: http://www.who.int /tb/country/data/profiles/en/ Accessed 2 October 2019.

4. Ministry of Health of Suriname. Five-Year Tuberculosis Plan, 2015 2020. Paramaribo: $\mathrm{MOH} ; 2015$.

5. World Bank. Suriname Data 2017. Washington, DC: World Bank; 2018. Available from: https://data.worldbank.org/country/Suriname Accessed 12 January 2019.

6. World Health Organization. Definitions and Reporting Framework for Tuberculosis. Geneva: WHO; 2014. Available from: http://apps.who int/iris/bitstream/handle/10665/79199/9789241505345_eng.pdf; jsessionid=F4ACA8EE35851B9A784EB4C867ACECE7? sequence $=1$ Accessed 2 October 2019.

7. Gunda DW, Nkandala I, Kavishe GA, Kilonzo SB, Kabangila R, Mpondo BC. Prevalence and risk factors of delayed sputum conversion among patients treated for smear positive PTB in northwestern rural Tanzania: a retrospective cohort study. J Trop Med. 2017:1-5. https://doi.org/10.1155/2017/5352906

8. Pefura-Yone EW, Kengne AP, Kuaban C. Nonconversion of sputum culture among patients with smear positive pulmonary tuberculosis in Cameroon: a prospective cohort study. BMC Infect Dis. 2014;14:138.

9. D'Souza KA, Zaidi SMA, Jaswal M, Butt S, Khowaja S, Habib SS, et al. Factors associated with month 2 smear nonconversion among Category 1 tuberculosis patients in Karachi, Pakistan. J Infect Public Health. 2017;11:283-5.

10. Kanda R, Nagao T, Tho NV, Ogawa E, Murakami Y, Osawa M, et al. Factors affecting time to sputum culture conversion in adults with pulmonary tuberculosis: a historical cohort study without censored cases. PloS One. 2015;10(11):e0142607.

11. Azarkar Z, Sharifzadeh G, Ebrahimzadeh A, Olumi S. Time to sputum smear conversion in smear-positive pulmonary tuberculosis patients and factors for delayed conversion. Iran J Med Sci. 2016;41:(1):44-7.

12. Djouma FN, Noubom M, Ateudjieu J, Donfack H. Delay in sputum smear conversion and outcomes of smear-positive tuberculosis patients: a retrospective cohort study in Bafoussam, Cameroon. BMC Infect Dis. 2015;15:139.

13. Bisognin F, Amodio F, Lombardi G, Bacchi Reggiani ML, Vanino E, Attard L, et al. Predictors of time to sputum smear conversion in patients with pulmonary tuberculosis under treatment. New Microbiol. 2019;42(3):171-5.

14. Kayigamba FR, Bakker MI, Mugisha V, De Naeyer L, Gasana M, Cobelens F, et al. Adherence to tuberculosis treatment, sputum smear conversion and mortality: a retrospective cohort study in 48 Rwandan clinics. PloS One. 2013;8(9):e73501.

15. Senkoro M, Mfinanga SG, Mørkve O. Smear microscopy and culture conversion rates among smear positive pulmonary tuberculosis patients by HIV status in Dar es Salaam, Tanzania. BMC Infect Dis. 2010;10:210.

16. Leung CC, Yew WW, Mok TYW, Lau KS, Wong CF, Chau CH, et al. Effects of diabetes mellitus on the clinical presentation and treatment response in tuberculosis. Respirol Carlton Vic. 2017; 22(6):1225-32

17. Jeyashree K, Kathirvel S, Shewade HD, Kaur H, Goel S. Smoking cessation interventions for pulmonary tuberculosis treatment outcomes. Cochrane Tobacco Addiction Group, ed. Cochrane Database Syst Rev. Available from: http://doi.wiley.com/10.1002/14651858 .CD011125.pub2 Accessed 3 September 2019.

18. Saffari M, Jolandimi HA, Sehat M, Nejad NV, Hedayati M, Zamani $\mathrm{M}$, et al. Smear grading and the Mantoux skin test can be used to predict sputum smear conversion in patients suffering from tuberculosis. GMS Hyg Infect Control. 2017;12:Doc12.

19. Mlotshwa M, Abraham N, Beery M, Williams S, Smit S, Uys M, et al. Risk factors for tuberculosis smear nonconversion in Eden district, Western Cape, South Africa, 2007-2013: a retrospective cohort study. BMC Infect Dis. 2016;16:365.

20. Caetano Mota P, Carvalho A, Valente I, Braga R, Duarte R. Predictors of delayed sputum smear and culture conversion among a Portuguese population with pulmonary tuberculosis. Rev Port Pneumol. 2012;18(2):72-9.

21. Shariff NM, Safian N. Diabetes mellitus and its influence on sputum smear positivity at the 2 nd month of treatment among pulmonary tuberculosis patients in Kuala Lumpur, Malaysia: a case control study. Int J Mycobacteriol. 2015;4(4):323-9. 
22. Mi F, Tan S, Liang L, Harries AD, Hinderaker SG, Lin Y, et al. Diabetes mellitus and tuberculosis: pattern of tuberculosis, two-month smear conversion and treatment outcomes in Guangzhou, China. Trop Med Int Health. 2013;18(11):1379-85.

23. Restrepo BI, Fisher-Hoch SP, Smith B, Jeon S, Rahbar MH, McCormick JB, et al. Mycobacterial clearance from sputum is delayed during the first phase of treatment in patients with diabetes. Am J Trop Med Hyg. 2008;79(4):541-4.

24. Balasubramanian R, Garg R, Santha T, Gopi PG, Subramani R, Chandrasekaran V, et al. PRN. Gender disparities in tuberculosis: report from a rural DOTS programme in south India. Int J TubercLung Dis.2004;8(3):323-33.

25. Nunn PP, Elliott AM, McAdam KP. Tropical respiratory medicine. 2 Impact of human immunodeficiency virus on tuberculosis in developing countries. Thorax. 1994;49(5):511-8. Available from: http://thorax.bmj.com/cgi/doi/10.1136/thx.49.5.511 Accessed 11 September 2019.

26. Centrum Infectieziektebestrijding. RIVM Laboratory analysis of 39 mycobacterium tuberculosis isolates from Suriname, 2012-2018. Available from: https://www.rivm.nl/over-het-rivm/organisatie /centrum-infectieziektebestrijding Accessed 14 October 2019.

Manuscript received on 27 July 2019. Revised version accepted for publication on 23 September 2019.

\section{Determinantes de la falta de conversión de la baciloscopia en pacientes con tuberculosis pulmonar con baciloscopia positiva en Suriname, 2010-2015}

ABSTRACT Objetivo. Determinar los factores relacionados con la falta de conversión de la baciloscopia en pacientes con tuberculosis pulmonar (TBP) en Suriname.

Métodos. Se llevó a cabo un estudio de casos y testigos con datos de vigilancia sistemática de la base de datos del programa nacional contra la tuberculosis de Suriname, se analizaron los casos de TBP notificados desde enero del 2010 hasta diciembre del 2015. Los casos fueron pacientes con TBP y baciloscopia positiva inicial cuyo resultado se volvió negativo al cabo de 2 meses del inicio del tratamiento. Los controles fueron pacientes con TBP y baciloscopia positiva inicial que presentaron resultados negativos de la baciloscopia durante el mismo período. Se usó un análisis de regresión logística multivariante para examinar las asociaciones entre los posibles factores de riesgo y la conversión de la baciloscopia.

Resultados. Los grupos etarios de mayores de 35 años (35-54 años, ORA, 2,7, IC 95 \%: 1,2-6,1; y mayores de 55 años, ORA, 2,5, IC 95 \%: 1,1-5,9) con carga bacilar elevada al inicio del estudio (ORA, 2,34, IC 95 \%: 1,2-4,8) presentaron una asociación significativa con retraso de la conversión de la baciloscopia.

Conclusiones. El programa nacional contra la tuberculosis de Suriname debe plantear estrategias para atender a los pacientes con un riesgo más alto de retraso de la conversión de la baciloscopia a fin de prevenir una mayor propagación de la enfermedad y resultados desfavorables del tratamiento. Este programa debe ampliar la recopilación de datos para incluir todos los factores de riesgo de retraso de la conversión de la baciloscopia y de esta manera fundamentar mejor la toma de decisiones y los estudios futuros.

Palabras clave Tuberculosis pulmonar; resultado del tratamiento; esputo; factores de riesgo; tuberculosis; Suriname. 


\section{Determinantes da não conversão da baciloscopia de escarro em pacientes com tuberculose pulmonar com baciloscopia positiva no Suriname, 2010-2015}

ABSTRACT Objetivo. Identificar os fatores associados à não conversão da baciloscopia de escarro em pacientes com tuberculose pulmonar no Suriname.

Métodos. Estudo de caso-controle conduzido baseado em dados de vigilância coletados rotineiramente de casos de tuberculose pulmonar notificados em janeiro de 2010 a dezembro de 2015 e registrados na base de dados do Programa Nacional de Combate à Tuberculose do Suriname. Os casos foram pacientes com tuberculose pulmonar com baciloscopia positiva cujos resultados ficaram negativos em dois meses após o início de tratamento. O grupo de controle foi formado por pacientes com tuberculose pulmonar e baciloscopia positiva inicial cujos resultados foram negativos no mesmo período. Uma análise de regressão logística multivariada foi realizada para examinar as associações entre os fatores de risco em potencial e a conversão da baciloscopia.

Resultados. Idade de 35 anos ou mais (35 a 54 anos, OR ajustado 2,7, IC 95\% 1,2-6.1; e 55 anos ou mais, OR ajustado 2,5, IC 95\% 1,1-5,9) e alta carga bacilar inicial (OR ajustado 2,34, IC 95\% 1,2-4,8) tiveram associação significativa com a conversão tardia da baciloscopia.

Conclusões. O Programa Nacional de Combate à Tuberculose do Suriname deve elaborar estratégias para contemplar os pacientes com maior risco de conversão tardia da baciloscopia para evitar propagar mais a doença e prevenir desfechos desfavoráveis no tratamento. Para subsidiar melhor a tomada de decisão e estudos futuros, o Programa de Tuberculose deve expandir a coleta de dados para abranger os fatores de risco para conversão tardia da baciloscopia.

Palavras-chave Tuberculose pulmonar; resultado do tratamento; escarro; fatores de risco; tuberculose; Suriname. 